J. Appl. Glycosci., 55, 25-33 (2008)

(C) 2008 The Japanese Society of Applied Glycoscience

Award Address: The Award of Merit of the 2007's JSAG

\title{
Food Biochemical Study on Fructans and Related Synthesis Enzymes
}

(Received November 5, 2007)

Norio Shiomi ${ }^{1, *}$

${ }^{1}$ Department of Food and Nutrition Sciences, Graduate School of Dairy Science Research, Rakuno Gakuen University (582, Bunkyodai, Midorimachi, Ebetsu 069-8501, Japan)

\begin{abstract}
There are more than 500 kinds of oligosaccharide occurring in nature, and all of these are synthesized by chemical and enzymatic reactions. Various studies have recently identified physiological and physical applications of such oligosaccharides in agricultural chemistry, nutrition and medicine. New technologies for the production of oligosaccharides from natural resources have been developed in the food industry and several oligosaccharides are now produced on a large scale as ingredients in animal feed. We have investigated the isolation of fructo-oligosaccharides, as well as the enzymatic synthesis of oligosaccharides that have functional activities as tertiary functional ingredients in food. We have studied the purification and characterization of several fructosyltransferases from asparagus roots and onion bulbs, including sucrose: sucrose 1fructosyltransferase (1-SST), fructan: fructan 1-fructosyltransferase (1-FFT), and the novel enzyme fructan: fructan $6^{\mathrm{G}}$-fructosyltransferase (6G-FFT). We have also reported that asparagus 1-FFT synthesized new functional oligosaccharides elongated with one or two additional fructose units by fructosyltransfer from 1-kestose to $4^{\mathrm{G}}$ - $\beta$-D-galactosylsucrose, and this compound selectively stimulates the growth of Bifidobacteria. For industrial applications, we attempted the isolation and expression of cDNAs encoding 6G-FFT, 1-FFT and 1-SST from asparagus plants. The cDNAs encoding 6G-FFT, 1-FFT and 1-SST were isolated from a cDNA library of asparagus leaves or roots, and the isolated cDNAs were designated aoft1, aoft 2 and aoft3, respectively. The deduced amino acid sequences of these cDNAs showed high homology with those of plant fructosyltransferases. Expression of these cDNAs was performed using Pichia pastoris. The recombinant protein from Pichia transformed with aoft1 produced $1^{\mathrm{F}}, 6^{\mathrm{G}}$-di- $\beta$-D-fructofuranosylsucrose, neokestose and sucrose from 1-kestose, while the transformant with an empty vector produced no saccharides. These results confirmed that 6G-FFT was expressed in $\boldsymbol{P}$. pastoris. Similarly, the recombinant protein from Pichia transformed with aoft 2 produced nystose from 1-kestose and the recombinant protein with aoft3 produced 1-kestose from sucrose. These results confirmed that 1-FFT and 1-SST were expressed in $P$. pastoris, and that the recombinant proteins had enzymatic properties similar to those of 6G-FFT, 1-FFT and 1-SST from asparagus roots. We then examined the conversion of substrate specificity from 6G-FFT to 1-FFT by point mutations in the $\beta$-fructosidase motif. The asparagine in this motif in aoft1 was changed to serine, and the mutant recombinant protein was characterized. We found that this amino acid substitution in wild-type aoft1 changed the substrate specificity from 6GFFT to 1-FFT. Finally, we studied the activities of the main enzymes involved in the synthesis and hydrolysis of fructo-oligosaccharides during the post-harvest life of onion bulbs and asparagus spears, and discuss the mechanisms triggering these enzyme activities, as well as the mechanisms by which fructo-oligosaccharides contribute to the quality and perishability of the vegetables.
\end{abstract}

Key words: fructan, fructo-oligosaccharide, fructosyltransferase, post-harvest, Pichia pastris

In our recent studies, we have investigated the enzymatic synthesis of novel non-digestible oligosaccharides that exhibit a range of activities as tertiary functional ingredients in foods. Non-digestible oligosaccharides, such as fructo-oligosaccharides, ${ }^{1}$ inulo-oligosaccharides ${ }^{2,3)}$ and fructosylxylosides, ${ }^{4)}$ derived from sucrose, inulin and xylose have been found to have several useful functions; for example, they do not elevate blood glucose or insulin concentrations, ${ }^{5,6)}$ have no hypocholesterolemic effects in blood, ${ }^{6)}$ promote the absorption of calcium ${ }^{7}$ and magnesium, ${ }^{7,8)}$ selectively stimulate the growth of Bifidobacteria ${ }^{6}$ ) and have probiotic effects in mice."

${ }^{*}$ Corresponding author $($ Tel. $+81-11-388-4754$, Fax. $+81-11-387-$ 5848, E-mail: n-shiomi@rakuno.ac.jp).

Abbreviations: 1-SST, sucrose : sucrose 1-fructosyltransferase; 1FFT, fructan : fructan 1-fructosyltransferase; 6G-FFT, fructan : fructan $6^{\mathrm{G}}$-fructosyltransferase; 1-KHE, 1-kestose hydrolyzing enzyme.
We have been focusing on the isolation of fructooligosaccharides $^{10-12)}$ and fructo-polysaccharide, ${ }^{13)}$ and the enzymatic synthesis of oligosaccharides in asparagus roots $^{14)}$ and onion bulbs. ${ }^{15)}$ The structures and enzymatic pathway of fructo-oligosaccharides in asparagus roots and onion bulbs ${ }^{16)}$ are shown in Fig. 1.

Although this scheme was presented at the first fructan symposium held at Bonn in 1988 and was published in the Journal of Plant Physiology in 1989, the scheme now includes new information. In onion bulbs, fructooligosaccharides were recently confirmed to be synthesized by a two-enzyme system comprising sucrose: sucrose 1-fructosyltransferase (1-SST) and fructan: fructan $6^{\mathrm{G}}$-fructosyltransferase (6G-FFT) together with fructan: fructan 1-fructosyltransferase (1-FFT) in recent works. ${ }^{17,18)}$

Fructo-oligosaccharides are reportedly synthesized by a three-enzyme system in asparagus roots: 1-SST (EC 2.4.1.99), ${ }^{19)}$ 1-FFT (EC 2.4.1.100) ${ }^{20)}$ and 6G-FFT (EC 


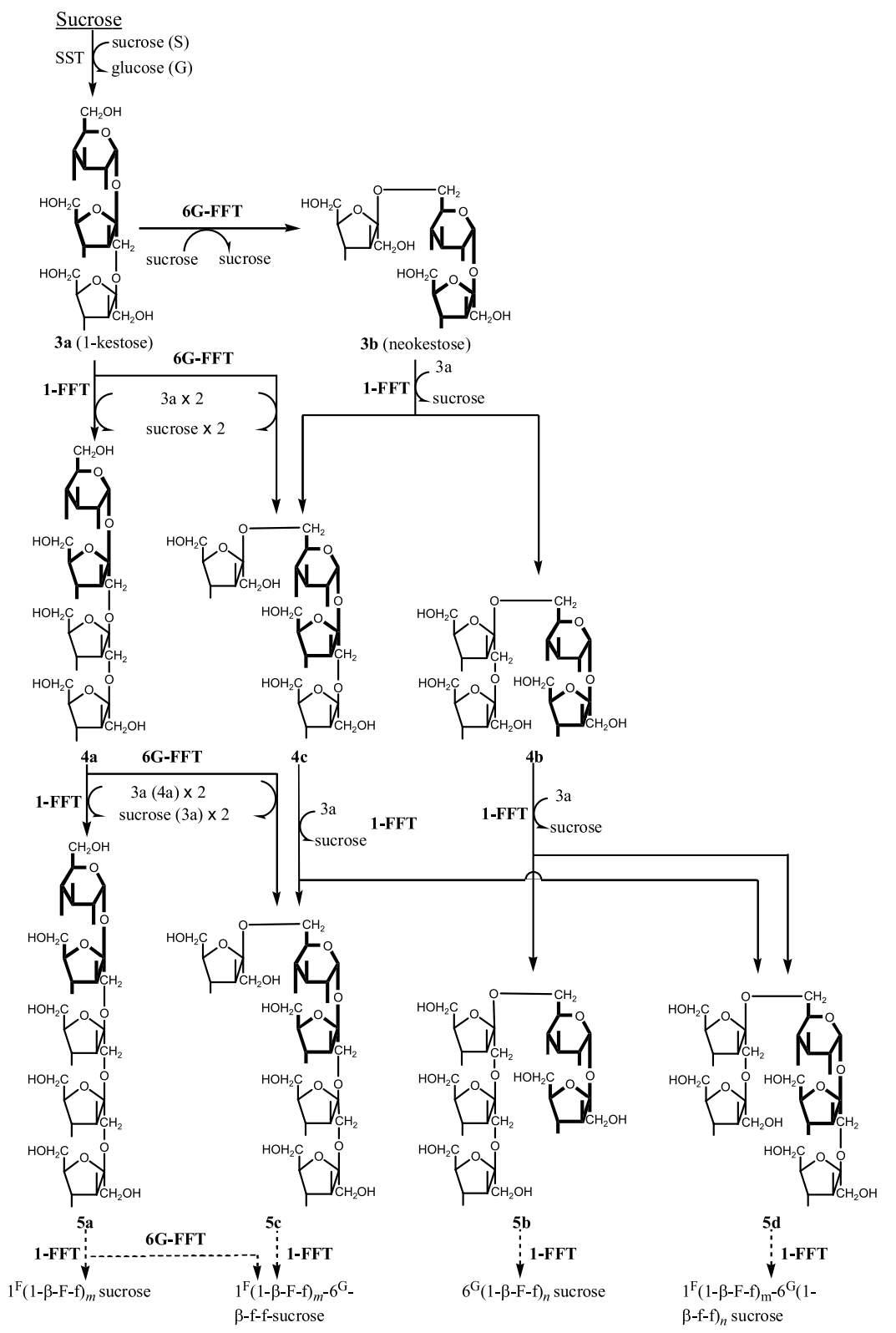

Fig. 1. Pathway of enzymatic synthesis of fructo-oligosaccharides in asparagus and onion plants. ${ }^{16)}$

$\mathrm{G}$, glucose; F, fructose; $\mathrm{S}$, sucrose; Inulin type oligosaccharides, $1^{\mathrm{F}}(1-\beta \text {-D-fructofuranosyl })_{m}$ sucrose [3a(1-kestose, 1 -kes): $m=1 ; 4 \mathrm{a}($ nystose, nys): $m=2$; 5 a(fructosylnystose, f-nys): $m=3 ; 6 \mathrm{a}: m=4 ; 7 \mathrm{a}: m=5]$; Inulin neotype oligosaccharides, $1^{\mathrm{F}}(1-\beta \text {-D-fructofuranosyl })_{m}-6 \mathrm{G}(1-\beta-\mathrm{D}-$ fructofuranosyl) ${ }_{n}$ sucrose [3b(neokestose, $n$-kes): $m=0, n=1 ; 4 \mathrm{~b}: m=0, n=2 ; 4 \mathrm{c}: m=1, n=1 ; 5 \mathrm{~b}: m=0, n=3 ; 5 \mathrm{c}: m=2, n=1 ; 5 \mathrm{~d}: m=1, n=2$ ] .

2.4.1.243, entry proposed by Shiomi). ${ }^{21-23)}$ We also reported the purification and characterization of $1-\mathrm{SST}^{24)} 1$ $\mathrm{FFT}^{17)}$ and $6 \mathrm{G}-\mathrm{FFT}^{17)}$ from the onion. We found that asparagus $1-\mathrm{SST}^{19)}$ or $1-\mathrm{FFT}^{25)}$ catalyzed fructosyltransfer from 1-kestose to non-reducing terminal fructosyl residues in some oligosaccharides, while 6G-FFT catalyzed fructosyltransfer from inulin type oligosaccharides to the glucose residues of oligosaccharides to produce inulin neotype oligosaccharides. ${ }^{21,23)}$

In this paper, we first report several oligosaccharides synthesized by the actions of 1-SST, 1-FFT and 6G-FFT from asparagus roots and onion bulbs. We then describe the cloning and expression of genes encoding 1-SST, 1FFT and 6G-FFT from asparagus as an initial study into utilizing the genes for production of oligosaccharide derivatives in the food industry. Finally, we discuss the metabolism of fructo-oligosaccharides in post-harvest onion and asparagus plants.

\section{Enzymatic preparation of fructo-oligosaccharides using fructosyltransferases (1-SST, 1-FFT and 6G- FFT)}

Fructosyltransferases from microorganisms, such as Aspergillus niger, ${ }^{26)}$ are currently used to prepare fructooligosaccharides in the Japanese food industry. In this case, fructosyltransferases produce fructo-oligosaccharides with a DP higher than 1-kestose; thus, the enzymes are unsuitable for preparation of 1-kestose. In contrast, asparagus $1-\mathrm{SST}^{19)}$ and Eurotium ${ }^{27)}$ or Scopulariopsis ${ }^{1)}$ fructosyltransferase can catalyze fructosyltransfer with sucrose to produce 1-kestose. We isolated and crystalyzed large amounts of 1-kestose for use as a food additive using the Eurotium enzyme. When asparagus 1-SST is applied to the production of fructo-oligosaccharides, only 1-kestose is obtained.

The synthesis of fructosyl-raffinose, -stachyose and -verbascose by 1-SST from asparagus root or by fructo- 
syltransferase from Eurotium is shown in Fig. 2. Raffinose, stachyose and verbascose are known to be present in soy beans. When extracted, these oligosaccharides are used in Japan as functional saccharide food additives, known as soy oligosaccharides. However, these saccharides have low solubility in water and lower promotion activity for Bifidobacteria than fructo-oligosaccharides. In order to improve the function of these saccharides, we attempted to synthesize new oligosaccharide derivatives of raffinose, stachyose or verbascose elongated with one unit of fructose. ${ }^{28)}$ Three oligosaccharides were synthesized from raffinose, stachyose and verbascose, and sucrose with asparagus 1-SST or Eurotium fructosyltransferase in large quantities, and were then isolated to study their physiological effects in rats and microorganisms.

We have also been investigating the purification and properties of asparagus1-FFT. We reported that asparagus $1-\mathrm{FFT}^{20)}$ preferentially catalyzed fructosyltransfer from 1kestose to neokestose to produce aspargosin-like saccharides via neokestose derivatives. In the study, we found that 1-FFT also catalyzed fructosyltransfer from 1-kestose to the fructosyl residue of terminal sucrose in other oligosaccharides, thereby producing oligosaccharides elongated with several units of fructose. Therefore, we attempted to synthesize oligosaccharides from 1-kestose and lactosucrose using purified asparagus 1-FFT. Lactosucrose elongated with several units of fructose were produced ${ }^{25)}$ using asparagus 1-FFT, as shown in Fig. 3. These fructosyllactosucroses improve intestinal conditions, thereby having a beneficial effect on overall health.

It is thought that inulin neotype oligosaccharides are preferentially hydrolyzed to inulin oligosaccharides by $\beta$ fructofuranosidase. For example, oligo $\beta$-fructofuranosidase from Bifidobacterium adolescentis G7 was previously reported to hydrolyze neokestose more rapidly than 1-kestose, and that Bifidobacteria utilize neokestose more effectively than 1 -kestose. ${ }^{29)}$ Therefore, inulin neotype oligosaccharides converted from inulin type oligosaccharides are expected to be preferentially utilized by Bifidobacteria. We thus attempted to convert inulin type oligosaccharides to inulin neotype oligosaccharides using purified asparagus 6G-FFT as shown in Fig. 4. Anion exchange

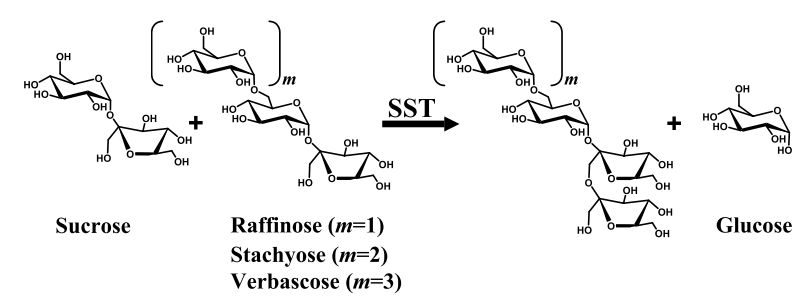

Fig. 2. Synthesis of fructosyl-raffinose, -stachyose and -verbascose with sucrose: sucrose 1-fructosyltransferase (1-SST) from Eurotium repens or onion seeds.

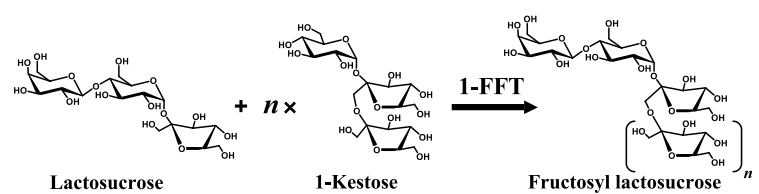

Fig. 3. Synthesis of fructosyl lactosucrose with fructan : fructan 1fructosyltransferase (1-FFT) from asparagus roots. chromatograms of inulin neotype oligosaccharides produced from inulintype oligosaccharides using asparagus 6G-FFT are shown in Fig. 5.

The upper part is the chromatogram for a reaction mixture containing inulin type oligosaccharides (from DP 4 to DP 10 or more) used as substrate with 6G-FFT at time 0 . The lower part is the chromatogram for reaction products formed from inulin type oligosaccharides with 6G-FFT at $24 \mathrm{~h}$. Inulin neotype oligosaccharides 3b, 4c, 4b, 5b, 5d, $5 \mathrm{c}, 6$ in, 7 in, 8 in and 9 in were observed.

A chromatogram of inulin neotype oligosaccharids produced from 1-kestose using asparagus 6G-FFT is shown in Fig. 6. At $0 \mathrm{~h}$, only the substrate 1-kestose was detected. At $24 \mathrm{~h}$, inulin neotype oligosaccharides 3b, 4c, $4 \mathrm{~b}, 5 \mathrm{c}, 5 \mathrm{~d}$ and $5 \mathrm{~b}$ were detected.

\section{Molecular characterization of asparagus fructo- syltransferase \\ 1) Cloning and expression of genes encoding fructo- syltransferases}

The cloning and expression of genes encoding 6G-FFT, 1-FFT and 1-SST were then studied for potential applications in the food industry. cDNAs encoding asparagus

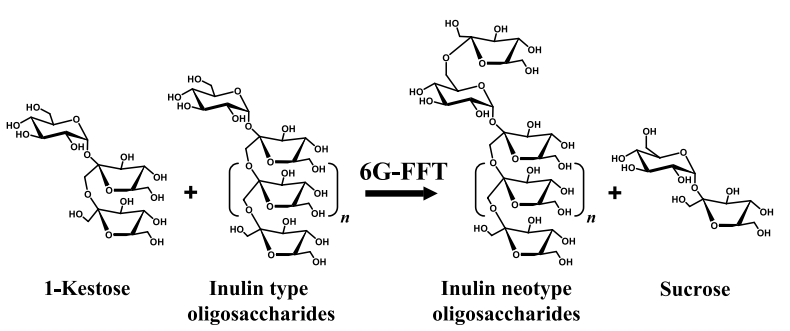

Fig. 4. Synthesis of inulin neotype oligosaccharide with fructan fructan $6^{\mathrm{G}}$-fructosyltransferase (6G-FFT) from asparagus plants.

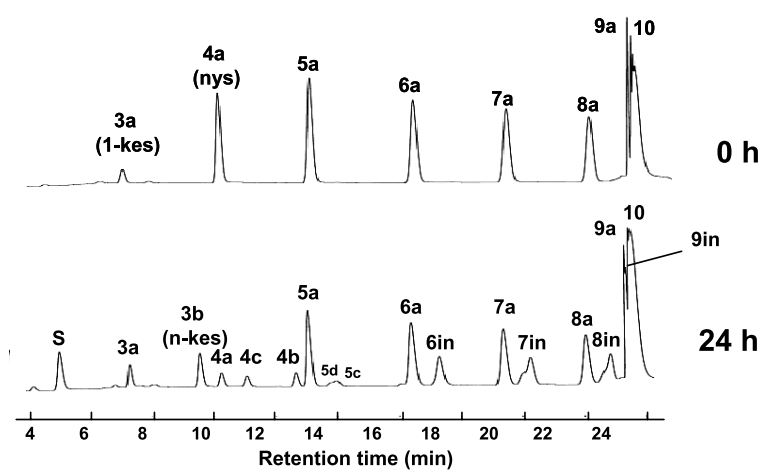

Fig. 5. Anion exchange chromatogram of inulin neotype oligosaccharides produced from inulin type oligosaccharides using fructan : fructan $6^{\mathrm{G}}$-fructosyltransferase (6G-FFT) from asparagus leaves.

A mixture of 6G-FFT $(25 \mu \mathrm{L}, 0.54 \mathrm{U})$, McIlvaine buffer $(\mathrm{pH} 5.5$, $25 \mu \mathrm{L}), 5 \%$ inulin type oligosaccharides $\left[1^{\mathrm{F}}(1-\beta-\mathrm{D}\right.$-fructofuranosyl) ${ }_{1 \rightarrow 9}$ sucrose $]$ and toluene (a trace amount) was incubated at $30^{\circ} \mathrm{C}$ for $96 \mathrm{~h}$. After the reaction was stopped by heating at $100^{\circ} \mathrm{C}$ for $3.5 \mathrm{~min}$, the reaction mixture was diluted 100 times with distilled water and an aliquot $(10 \mu \mathrm{L})$ was injected to HPAEC. Inulin type oligosaccharide: $1^{\mathrm{F}}(1-\beta \text {-D-fructofuranosyl })_{m}$ sucrose [3a (1-kestose): $m=2$; 5a (fructosylnystose): $m=3 ; 6 \mathrm{a}: m=4 ; 7 \mathrm{a}: m=5 ; 8 \mathrm{a}: m=6$; 9a: $m=7, \quad 10: \quad m \geq 8]$; Inulin neotype oligosaccharides, $1^{\mathrm{F}}(1-\beta-\mathrm{D}-$ fructofuranosyl $)_{m}-6^{\mathrm{G}} \quad(1-\beta \text {-D-fructofuranosyl })_{n}$ sucrose $[3 \mathrm{~b}$ (neokestose: $m=0, n=1 ; 4 \mathrm{~b}: m=0, n=2 ; 4 \mathrm{c}:, m=1, n=1 ; 5 \mathrm{c}: m=2, n=1 ; 5 \mathrm{~d}$ : $m=1, n=2$; 6in-9in: $m+n=4-7$ ). 


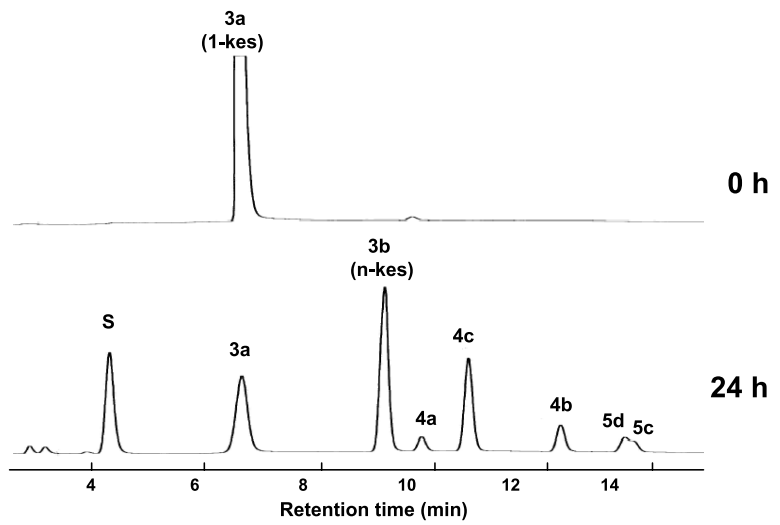

Fig. 6. Anion exchange chromatogram of inulin neotype oligosaccharides produced from 1-kestose using fructan: fructan $6^{\mathrm{G}}$-fructosyltransferase (6G-FFT) from asparagus leaves.

fructosyltransferases were obtained by degenerate PCR and cDNA library screening. The obtained cDNAs (aoftl, aoft2 and aoft3) resembled other plant fructosyltransferases and invertases.

Isolated aoft1 consisted of $2201 \mathrm{bp}$, and contained an open reading frame (ORF) of $1833 \mathrm{bp}$ and a poly(A) sequence at the $3^{\prime}$-end. The ORF encoded a polypeptide of 610 amino acids, as shown in Fig. 7. The molecular mass and $p \mathrm{I}$ of the deduced polypeptide (designated AoFT1) were calculated to be $68,311 \mathrm{Da}$ and 5.4, respectively. The deduced polypeptide had six potential $\mathrm{N}$ glycosylation sites. The primary sequence of aoft 1 showed the highest identity, $68 \%$, with onion 6G-FFT. ${ }^{23,30)}$ A recombinant protein was obtained by expression of aoft1 in P. pastoris in order to investigate its enzymatic properties.

When reacting recombinant AoFT1 protein with 100 $\mathrm{mm} 1$-kestose for $1 \mathrm{~h}$, the initial products were $4 \mathrm{c}$ and sucrose, indicating that the recombinant protein catalyzed fructosyltransfer from 1-kestose to the 6th $\mathrm{OH}$ of the glucosyl residue of another 1-kestose, with liberation of sucrose, as shown in Fig. 8. After incubation for $2 \mathrm{~h}$, neokestose was produced. This protein catalyzed fructosyltransfer from 1-kestose to the 6th $\mathrm{OH}$ of the glucosyl residue of the liberated sucrose. In addition to oligosac- charides of the inulin neotype resulting from 6G-FFT activity, prolonged incubation of recombinant AoFT1 protein with 1-kestose produced a small amount of nystose, indicating that the protein also has weak 1-FFT activity. The reaction mixture at $24 \mathrm{~h}$ also contained $4 \mathrm{~b}, 5 \mathrm{c}$ and 5 d. These oligosaccharides were previously reported to be synthesized from 1-kestose by $6 \mathrm{G}^{-\mathrm{FFT}^{16,21,22)}}$ and 1-FFT ${ }^{16,20)}$ activities in asparagus and in onion. ${ }^{15)}$

Consequently, the AoFT1 recombinant protein expressed in $P$. pastoris was confirmed to be 6G-FFT.

Isolated aoft 2 consisted of $2190 \mathrm{bp}$, and contained an ORF of $1875 \mathrm{bp}$ and a poly(A) sequence at the $3^{\prime}$-end. The ORF encoded a polypeptide of 624 amino acids, as shown in Fig. 9. The molecular mass and $p \mathrm{I}$ of the deduced polypeptide (designated AoFT2) were calculated to

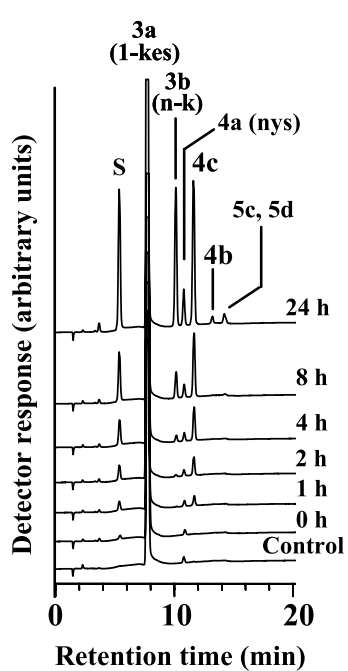

Fig. 8. High performance anion-exchange chromatograms of the reaction products formed by recombinant protein AoFT1.

A reaction mixture containing AoFT1 was incubated with 100 $\mathrm{mM}$ 1-kestose. As a control, reaction mixtures containing protein extract obtained by using the empty vector were incubated with each substrate for $24 \mathrm{~h}$. S, sucrose; 1-kes, 1-kestose; n-k, neokestose; nys, nystose; $4 \mathrm{c}, 1^{\mathrm{F}}, 6^{\mathrm{G}}$-di- $\beta$-D-fructofuranosylsucrose; $4 \mathrm{~b}, 6^{\mathrm{C}}$ (1- $\beta$-D-fructofuranosyl $)_{2}$ sucrose; $5 \mathrm{c}, 1^{\mathrm{F}}(1-\beta \text {-D-fructofuranosyl })_{2}-6^{\mathrm{G}}-\beta$ D-fructofuranosylsucrose; $5 \mathrm{~d}, 1^{\mathrm{F}}-\beta-\mathrm{D}-$ fructofuranosyl- $6^{\mathrm{G}}(1-\beta-\mathrm{D}$-fructofuranosyl $)_{2}$ sucrose.

\begin{tabular}{|c|c|c|c|c|c|c|}
\hline 10 & 20 & 30 & 40 & 50 & 60 & 70 \\
\hline MATSLQAPIL & GSRPPRRTLR & FLSFALFSAL & VLVVASFSSR & KSESGSGLRS & GSVEPEYAWT & NQMLTWQRAG \\
\hline 80 & 90 & 100 & 110 & 120 & 130 & 140 \\
\hline FHFRTVKNYM & NDPSGPMYYK & GWYHLFYQHN & PNYAYWGDIS & WGHAVSRDLL & NWFHLPVAVK & PDRWYDIYGV \\
\hline $1 \overline{\overline{50}}$ & 160 & 170 & 180 & 190 & 200 & 210 \\
\hline TTGSITVMPD & DGRVVMLYTG & GTKEKYQIMS & VAMAADPSDP & LLVEWVKYDE & VNPVLRPPPG & IGLTDF'RDPN \\
\hline 220 & 230 & 240 & 250 & 260 & 270 & 280 \\
\hline PIWYNTTDST & WQLVIGSKND & SLQHTGIAMV & YTTKDFINLT & LLPGVLHSVD & HVGMWECVDL & FPVASSGPLI \\
\hline 290 & 300 & 310 & 320 & 330 & 340 & 350 \\
\hline GRGLDRSMML & ADNVKHVLKA & SMNDEWHDYY & AIGSYDVATH & RWVPDDESVD & VGIGMRIDWG & KFYASRTFYD \\
\hline 360 & 370 & 380 & 390 & 400 & 410 & 420 \\
\hline PVKERRVMWG & YVGETDSGDA & DVAKGWASFQ & GIPRTVLFDV & KTGTNVLTWP & IEEVESLRMT & RKDFSDIVVN \\
\hline 430 & 440 & 450 & 460 & 470 & 480 & 490 \\
\hline KGSTVELHVG & DANQLDIEAE & FEMDKDALET & AIEADIGYNC & SSSGGAVSRG & VLGPFGLFVL & ANQDLTELTA \\
\hline 500 & 510 & 520 & 530 & 540 & 550 & 560 \\
\hline ZFYVSRATD & SLHTHLCHD & MRSSKANDI & RVVGGTFT & LDGELLSLR & ILVDHSIVES & FAQGGRTSAT \\
\hline 570 & 580 & 590 & 600 & 610 & & \\
\hline SRVYPTEAIY & ERARVFLFNN & ATGATITAKA & VKVWQMNSTS & NQYYPFTSSN & & \\
\hline
\end{tabular}

Fig. 7. Deduced amino acid sequence of aoft1.

AoFT1, deduced amino acid sequence of asparagus fructan: fructan $6^{\mathrm{G}}$-fructosyltransferase (accession no. AB084283). Potential $N$ glycosylation sites in the sequence of AoFT1 are marked by underlines. Double underlined sequences indicate the conserved region in the GH 32 family. 
be 68,837 Da and 4.97 , respectively. The deduced polypeptide had five potential $\mathrm{N}$-glycosylation sites. The primary sequence of aoft 2 showed highest identity, 64\%, with asparagus 6G-FFT. ${ }^{23)}$ Recombinant AoFT2 protein was obtained by expression of aoft 2 in $P$. pastoris to investigate its enzymatic properties.

When reacting the recombinant AoFT2 protein with $100 \mathrm{~mm}$ 1-kestose for $1 \mathrm{~h}$, the initial products were nystose and sucrose, as shown in Fig. 10. Prolonged incubation of AoFT2 protein with 1-kestose also produced fructosylnystose. Inulin neotype fructo-oligosaccharides such as neokestose $4 \mathrm{c}$ were not detected.

These results indicate that AoFT2 has 1-FFT activity, but not 6G-FFT activity. AoFT2 protein did not show any 1-SST or 6-SFT activity in the reaction with $100 \mathrm{~mm} \mathrm{su}-$ crose as a sole substrate (date is not shown). Consequently, AoFT2 protein expressed in P. pastoris was confirmed to be 1-FFT and was secreted into the culture broth.

Isolated aoft3 consisted of $2107 \mathrm{bp}$, and contained an ORF of $1887 \mathrm{bp}$ and a poly(A) sequence at the 3 -end. The ORF encoded a polypeptide of 628 amino acids, as

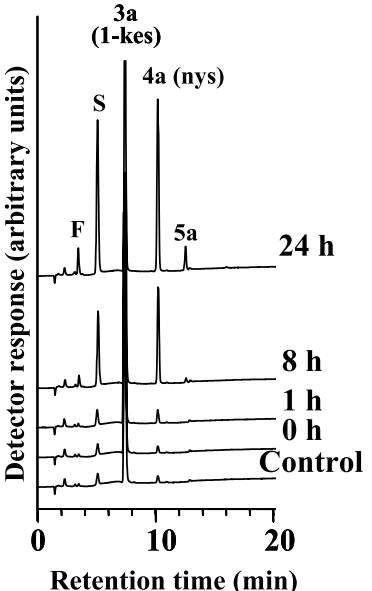

Fig. 10. High performance anion-exchange chromatograms of the reaction products formed by recombinant protein AoFT2.

A reaction mixture containing AoFT2 was incubated with 100 $\mathrm{mM}$ 1-kestose. As a control, reaction mixtures containing protein extract obtained by using the empty vector were incubated with each substrate for $24 \mathrm{~h}$. S, 3a, 4a and 5a represent the same saccharides as listed in Figs. 1 and 8 .

\begin{tabular}{|c|c|c|c|c|c|c|c|}
\hline 10 & 20 & 30 & 40 & 50 & 60 & 70 & 80 \\
\hline MGSPDLESHA & PLVREAALES & RPPRRNLGLL & LLGPLVASLL & ALVYFLGDKP & GSSQGLGSSS & GSDEDEFPWT & DRMLKWHHTA \\
\hline 90 & 100 & 110 & 120 & 130 & 140 & 150 & 160 \\
\hline FHFQPPRNFM & SDPSGPIYYR & GWYHFFYQHN & TNAAYWGHIA & WGHAATPDLL & NWVHLPVAVY & PDHWYDIEGD & WTGSVAALPD \\
\hline $1 \overline{70}$ & 180 & 190 & 200 & 210 & 220 & 230 & 240 \\
\hline GRVVMLFTGG & VGAVGNELAQ & VVNVAWAADP & DDPLLTRWVK & QEGNPVLVSP & PGIGLKDFRD & PNPAWYDSSS & STWYVLVGSK \\
\hline 250 & 260 & 270 & 280 & 290 & 300 & 310 & 320 \\
\hline NDSLSHTGIA & LVYTTTDFLS & YTLLPGILHS & VDIVGMWECT & DLYPVSVSGP & STHLGLENSV & PPGENVKHVL & KAGLNDEWHD \\
\hline 330 & 340 & 350 & 360 & 370 & 380 & 390 & 400 \\
\hline YYAIGTYDRE & GNKWTPDDES & LDVGIGLRYD & WGKFYASRTF & YDPVKRRRVL & WGYVGETDTR & SVDVQKGWAS & VEGLPRTVLF \\
\hline 410 & 420 & 430 & 440 & 450 & 460 & 470 & 480 \\
\hline DVKTGSNLLT & WPAEEVESLR & SSSKNFSNIA & IAAGSTVHLD & VEDANQLDIE & AEFVIKKEEL & ELAIQADVNY & NCSTSDGASQ \\
\hline 490 & 500 & 510 & 520 & 530 & 540 & 550 & 560 \\
\hline RGLLGPFGLL & VLANQDLSEQ & TATYFYVGRG & TDGSLQTHLC & QDELRSSKAN & QITKRVVGHT & VPVLDDETLT & LRILVDHSIV \\
\hline 570 & 580 & 590 & 600 & 610 & 620 & & \\
\hline
\end{tabular}

ESYAQGGRAS TTSRVYPTQA IYEDAKVFLF NNATGATVIA KSVKIWQMSP TSNRSHGYPG SQAL

Fig. 9. Deduced amino acid sequence of aoft2.

AoFT2, the deduced amino acid sequence of asparagus fructan : fructan 1-fructosyltransferase (accession no. AB115554). Potential Nglycosylation sites in the sequence of AoFT2 are marked by underlines. Double underlined sequences indicate the conserved region in the GH32 family.

\begin{tabular}{|c|c|c|c|c|c|c|c|}
\hline 10 & 20 & 30 & 40 & 50 & 60 & 70 & 80 \\
\hline ASPSDLESP & PTLSAQLLES & RPPRSKLRLV & ALTLTAAAFL & VALALFLADG & SASRFVSGLA & RKLRSDPIKE & HDYPWTNEML \\
\hline 90 & 100 & 110 & 120 & 130 & 140 & 150 & 160 \\
\hline WQRSGFHFQ & PAKNFQSDPN & AAMYYKGWYH & FFYQYNPTGT & AWDYTISWGH & AVSRDLIHWL & HLPMAMVPDH & WYDAKGVWSG \\
\hline 170 & 180 & 190 & 200 & 210 & 220 & 230 & 240 \\
\hline STLLPDGRV & IVLYTGGTPE & LVQVQNLAVP & ADASDPLLLK & WKKSSVNPIL & VPPPGIGTSD & FRDPFPIWYN & ETDSNWHVLI \\
\hline 250 & 260 & 270 & 280 & 290 & 300 & 310 & 320 \\
\hline SKDSNHHGI & VLLYKTKDFF & NFTLLPSLLH & TSTQSVGMFE & CVDLYPVATG & GPLSNRGLEM & SVDLSNGGIK & HVLKASMDEE \\
\hline 330 & 340 & 350 & 360 & 370 & 380 & 390 & 400 \\
\hline HDYYAIGTF & DLDSFKWTPD & DPSIDVGVGL & RYDWGKFYAS & KTFFDTEKQR & RILWGYVGEV & DSKDDDKMKG & WATLQNIPRT \\
\hline 410 & 420 & 430 & 440 & 450 & 460 & 470 & 480 \\
\hline LLDTKTQSN & LIIWPVEEVE & TDGNIFN & AGSSV & ASQL & FELDN & IEAD & VTYNCSTSGG \\
\hline 490 & 500 & 510 & 520 & 530 & 540 & 550 & 560 \\
\hline LGPF & VLANQDL & YFYV & GDLRT & LRSS & GDIVKRVV & LHGE & RILVDH \\
\hline 570 & 580 & 590 & 600 & 610 & 620 & 630 & \\
\hline
\end{tabular}

Fig. 11. Deduced amino acid sequence of aoft3.

AoFT3, the deduced amino acid sequence of asparagus sucrose : sucrose 1-fructosyltransferase (accession no. AB115555). Potential $N$ glycosylation sites in the sequence of AoFT3 are marked by underlines. Double underlined sequences indicate the conserved region in the GH32 family. 


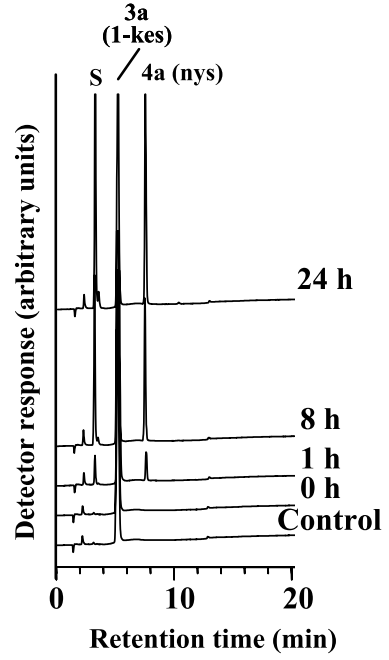

Fig. 12. High performance anion-exchange chromatograms of the reaction products formed by recombinant protein AoFT3.

A reaction mixture containing AoFT3 was incubated with 100 $\mathrm{mM}$ sucrose. As a control, reaction mixtures containing protein extract obtained by using the empty vector were incubated with each substrate for $24 \mathrm{~h}$. G, glucose; $\mathrm{S}$ and $3 \mathrm{a}$ represent the same saccharides as listed in Fig. 8.

shown in Fig. 11. The molecular mass and $p \mathrm{I}$ of the deduced polypeptide (designated AoFT3) were calculated to be 70,073 $\mathrm{Da}$ and 5.4, respectively. The deduced polypeptide had five potential $N$-glycosylation sites.

The primary sequence of aoft 3 showed the highest identity, $71 \%$, with onion 1-SST. ${ }^{31)}$ Recombinant AoFT3 protein was obtained by expression of aoft3 in $P$. pastoris to investigate its enzymatic properties.

When reacting AoFT3 protein with $100 \mathrm{~mm}$ sucrose for $1 \mathrm{~h}$, the initial products were 1-kestose and glucose, as shown in Fig. 12. Prolonged incubation of AoFT3 with 1kestose also produced small amounts of nystose. Inulin neotype fructo-oligosacchrides, such as neokestose 4c, were not detected. These results indicate that AoFT3 has 1-SST activity. The AoFT3 protein expressed in P. pastoris was confirmed to be 1-SST.

2) Conversion of 6G-FFT to 1-FFT by point mutation in a $\beta$-fructosidase motif.

Asparagus fructosyltransferases also belong to glycoside hydrolase family 32 , which includes invertase and fructosyltransferase from plants, and invertase, inulinase and levanase from bacteria and fungi. ${ }^{32)}$ Recombinant AoFT1, AoFT2 and AoFT3 proteins contained some of the conserved amino acid sequences observed in various fructosyltransferases and invertases, as shown in Fig. 13.

Two catalytic motifs were confirmed to be NDPN and $\mathrm{EC}$ in the primary sequence of yeast invertase by affinity labeling and site-directed mutagenesis. ${ }^{33,34)}$ The Asp (D) and Glu (E) residues in each motif in yeast invertase were identified as nucleophiles and proton donors, respectively. AoFT1, AoFT2 and AoFT3 possess the putative catalytic residues conserved among other plant enzymes belonging to this family, and the sequences around these residues were also highly conserved.

The asparagine in the $\beta$-fructosidase motif in AoFT1 was changed to a serine, similarly to AoFT2. Site-directed mutant of the amino acid residue was performed and the mutant recombinant protein was characterized. When 100

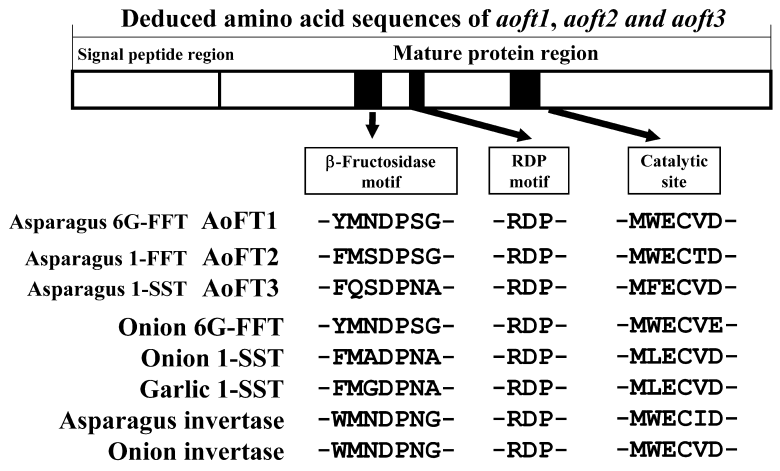

Fig. 13. Comparison of amino acid sequences of highly conserved regions of asparagus fructosyltransferases with those of plant fructosyltransferases and invertases.
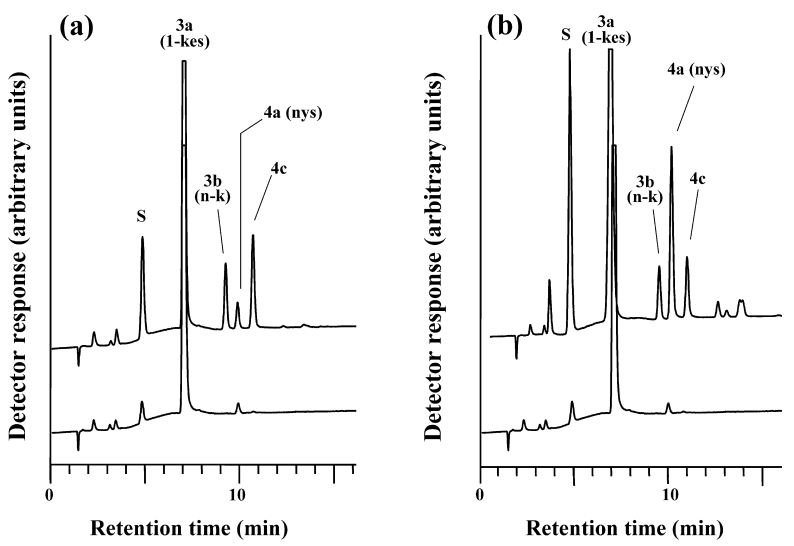

Fig. 14. High performance anion-exchange chromatograms of the reaction products formed from $100 \mathrm{~mm} 1$-kestose by recombinant 6G-FFT wild type (a) or mutant N81S (b). S, $3 a, 3 b, 4 a, 4 b$ and $4 c$ represent the same saccharides as listed in Fig. 8.

mM 1-kestose was given as a sole substrate, AoFT1 mutant protein (N81S) mainly produced nystose, while wildtype AoFT1 produced $4 \mathrm{c}$ or neokestose, as shown in Fig. 14. These results suggest that amino acid substitution in the $\beta$-fructosidase motif of wild-type AoFT1 altered substrate specificity, from 6G-FFT to 1-FFT, and was similar to those observed in onion bulbs. ${ }^{35)}$

\section{Post-harvest metabolism of fructo-oligosac- charides in onion and asparagus plants}

Alongside the studies on fructo-oligodsaccharide accumulation during seed development ${ }^{36)}$ and bulbing, ${ }^{37)}$ we also studied the main enzyme activities involved in the synthesis and the hydrolysis of fructo-oligosaccharides during the pre-harvest ${ }^{38)}$ (growth), and post-harvest ${ }^{38,39)}$ (storage) life of onion bulbs and asparagus spears, ${ }^{40)}$ although present knowledge is insufficient to clearly explain the mechanisms triggering enzymes or the mechanisms by which fructo-oligosaccharides contribute to bulb quality and perishability. ${ }^{39}$

Storage of onion bulbs for 6 months causes a decrease $^{41,42)}$ in the contents of glucose, fructose and sucrose, as shown by Fig. 15. Fructan contents also decrease significantly after this period, and highly polymerized fructans (DP 5 to 12) were strongly hydrolyzed. However, tri and tetra saccharides appear to play a regulatory role between the highly polymerized and disaccharides by regulating fructan hydrolase activity and preventing excessive 
accumulation of fructose and sucrose, as reported previously. ${ }^{41-44)}$ To illustrate the kinetics of fructooligosaccharide degradation during bulb storage, the comparative ratio of degrading enzymes to synthesizing enzymes was determined during storage, as shown in Fig. 16. The ratio was low at the beginning of storage, ranging between 0.31 and 0.45 , and it peaked at 2.29 during week 12, before decreasing abruptly to values 2-fold higher than those observed during the beginning of the experiment (between 0.75 and 1.26). These results indicate that fructan degradation is controlled by the balance between the different fructo-oligosaccharides of the bulbs. ${ }^{45,46)}$ Linear regression of fructo-oligosaccharide content of three onion cultivars is shown by Fig. 17. Linear regressions were similar under the three temperature regi-

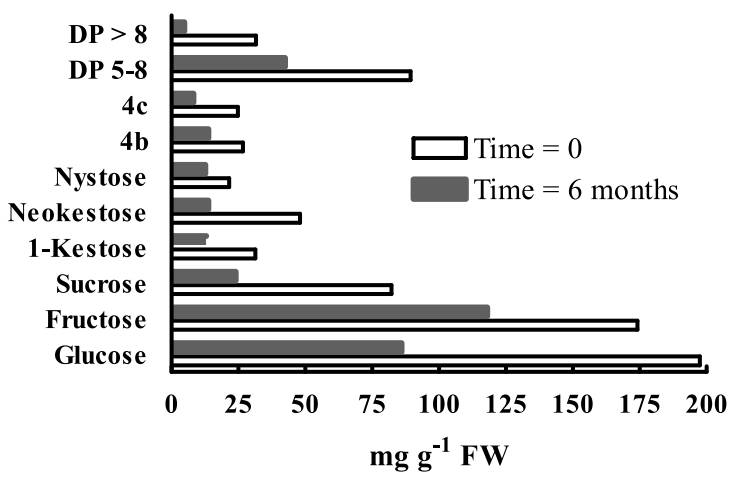

Fig. 15. Effect of storage time on contents of glucose, fructose, sucrose and fructo-oligosaccharides in onion bulbs kept 6 months at $20^{\circ} \mathrm{C}$.

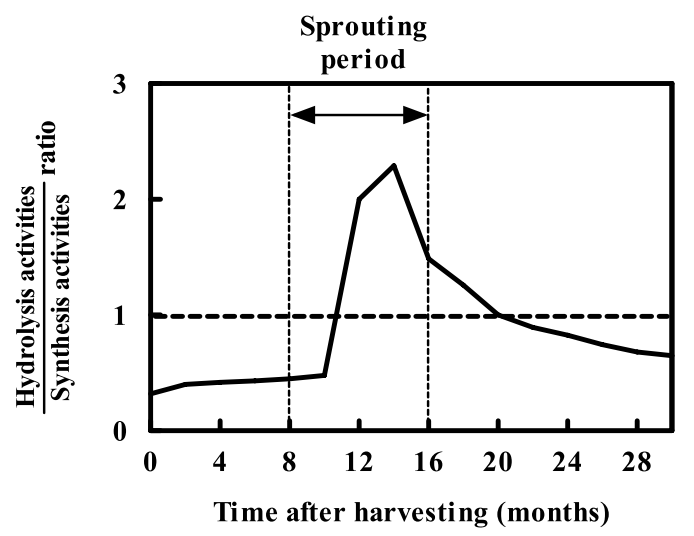

Fig. 16. Profile of the estimated ratio of the enzyme activities of the hydrolysis to those of the synthesis in onion bulb tissues under different temperatures.

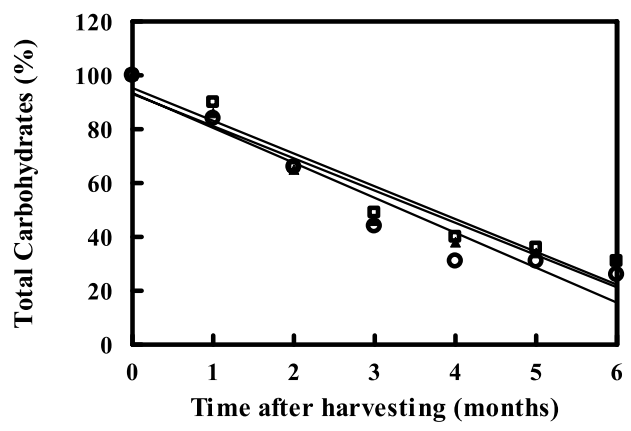

Fig. 17. Linear regression lines and coefficient of determination $\left(r^{2}\right)$ of the total carbohydrates versus keeping time after harvesting at different temperatures

$\square, 10^{\circ} \mathrm{C} ; \boldsymbol{\Delta}, 15^{\circ} \mathrm{C} ; \bigcirc, 20^{\circ} \mathrm{C}$ mens. As shown by the equations for the linear regression curves, the coefficient of regression $\left(\boldsymbol{R}^{2}\right)$ ranged between 0.950 and $0.987,0.947$ and 0.999 , and 0.917 and 0.978 for the Yellow Spanish (YS), Red Amposta (RA) and Tenshin $(\boldsymbol{T} \boldsymbol{s})$ cultivars, respectively. This indicates that, in the range studied, mobilization of fructo-oligosaccharides during re-growth of onion bulbs occurs independently of temperature. ${ }^{47}$

Studies on fructo-oligosaccharide degradation in onion bulbs of different cultivars during long-term storage at different temperatures have shown that hydrolysis of fructo-oligosaccharides is more rapid at the beginning of storage, and that hydrolysis increases with temperature. The results also showed that low temperatures did not slow down hydrolysis, even though fructo-oligosaccharide hydrolysis occurs more rapidly at high temperatures. The various data obtained to date suggest that degradation of fructo-oligosaccharides in stored onions may be more strongly influenced by the physiological process of sprouting, and may depend on the demand by growth tissues.

Comparatively extensive literature reported on the metabolism of fructo-oligosaccharides in asparagus plants during growth, while post-harvest life literature reported mainly on saccharides. ${ }^{40)}$ However, nothing has been reported for the metabolism of fructo-oligosaccharides except the work of Shiomi et al ${ }^{48)}$ The results showed that only short chain fructo-oligosaccharides (1-kestose and nystose) are present and their contents in the spears is very low compared to those of glucose, fructose and sucrose. They also showed the metabolizing enzymes of these fructo-oligosaccharides play a role in the balance of sugars between the bottom and the top of the spears where high catabolic activities were observed. ${ }^{48)}$ These results suggest that high fructo-oligosaccharede content in asparagus spears may extend the rapid decline of sugars in the top portion.

The author is grateful to Dr. Shuichi Onodera, Rakuno Gakuen University; Dr. Keiji Ueno, Koen Gakuen Women's College; Dr. Akira Kawakami and Dr. Midori Yoshida, National Agricultural Center for Hokkaido Region; Dr. Noureddine Benkeblia, Rakuno Gakuen University and Dr. Akira Yamamori, Ohtaka Kohso Co. Ltd. for their excellent contributions to this work.

\section{REFERENCES}

1 ) H. Takeda, K. Sato, S. Kinoshita and H. Sasaki: Production of 1-kestose by Scopulariopsis brevicaulis. J. Ferment. Bioeng., 77, 386-389 (1994).

2 ) S. Onodera and N. Shiomi: Purification and substrate specificity of endo-type inulinase from Penicillum purpurogenum. Agric. Biol. Chem., 52, 2569-2576 (1988).

3 ) S. Onodera, T. Murakami, H. Mori, H. Ito, H. Matsui, M. Honma, S. Chiba and N. Shiomi: Molecular cloning and nucleotide sequences of cDNA and gene encoding endo-inulinase from Penicillum purpurogenum. Biosci. Biotechnol. Biochem., 60, 1780-1785 (1996).

4 ) H. Takeda and S. Kinoshita: Production of fructosylxyloside by Scopulariopsis brevicaulis. sp. J. Ferment. Bioeng., 79, 242-246 (1995).

5 ) Y. Fukumori, S. Onodera and N. Shiomi: Nutritional characteristics of substances related to pentose and sugar alcohol. $J$. Appl. Glycosci., 48, 205-213 (2001). 
6 ) M. Hirayama and H. Hidaka: Production and utilization of microbial fructans. in Science and Technology of Fructans, M. Suzuki and N. J. Chatterton, eds., Boca Raton, FL, CRC Press, pp. 290-294 (1993).

7 ) H. Mineo, H. Hara, H. Kikuchi, H. Sakurai and F. Tomita: Various indigestible saccharides enhance net calcium transport from the epithelium of the small and large intestine of rats in vitro. J. Nutr., 131, 3243-3246 (2001).

8 ) A. Ohta, M. Ohtuki, S. Baba, T. Adachi, T. Sakata, E. Sakaguchi: Calcium and magnesium absorption from the colon and rectum are increased in rats fed fructooligosaccharides. $J$. Nutr., 125, 2417-2424 (1995).

9 ) N. Yoshida, W. Satou, S. Hata, Y. Takeda, S. Onodera, K. Ando and N. Shiomi: Effects of 1-kestose and nystose on the intestinal microorganisms and immune system in mice. $J$. Appl. Glycosci., 53, 175-180 (2006).

10) N. Shiomi, J. Yamada and M. Izawa: Isolation and identification of fructo-oligosaccharides in roots of asparagus (Asparagus officinalis L.). Agric. Biol. Chem., 40, 567-575 (1976).

11) N. Shiomi, J. Yamada and M. Izawa: A novel pentasaccharide in the roots of asparagus (Asparagus officinalis L.). Agric. Biol. Chem., 43, 1375-1377 (1979).

12) N. Shiomi: Two novel hexasaccharides from the roots of Asparagus officinalis. Phytochemistry, 20, 2581-2583 (1981).

13) N. Shiomi: Structure of fructopolysaccharide (asparagosin) from roots of asparagus (Asparagus officinalis L.). New Phytol ., 123, 263-270 (1993).

14) N. Shiomi, J. Yamada and M. Izawa: Synthesis of several fructo-oligosaccharides by asparagus fructosyltransferases. $\mathrm{Ag}$ ric. Biol. Chem., 43, 2233-2244 (1979).

15) N. Shiomi, S. Onodera and H. Sakai: Fructo-oligosaccharide content and fructosyltransferase activity during growth of onion bulbs. New Phytol., 136, 105-113 (1997).

16) N. Shiomi: Properties of fructosyltransferases involved in the synthesis of fructan in Liliaceous plants. J. Plant Physiol., 134, 151-155 (1989).

17) M. Fujishima, H. Sakai, K. Ueno, N. Takahashi, S. Onodera, N. Benkeblia and N. Shiomi: Purification and characterization of a fructosyltransferase from onion bulbs and its key role in the synthesis of fructo-oligosaccharides in vivo. New Phytol., 165, 513-524 (2005).

18) T. Ritsema, J. Joling and S. Smeekens: Patterns of fructan synthesized by onion fructan: fructan $6^{\mathrm{G}}$-fructosyltransferase expressed in tobacco BY2 cells- is fructan: fructan 1fructosyltransferase needed in onion? New Phytol., 160, 61-67 (2003).

19) N. Shiomi and M. Izawa: Purification and characterization of sucrose: sucrose 1-fructosyltransferase from the roots of asparagus (Asparagus officinalis L.). Agric. Biol. Chem., 44, 603-614 (1980).

20) N. Shiomi: Purification and characterisation of $1^{\mathrm{F}}$-fructosyltransferase from the roots of asparagus (Asparagus officinalis L.). Carbohydr. Res., 99, 157-169 (1982).

21) N. Shiomi: Purification and characterisation of $6^{\mathrm{G}}$-fructosyltransferase from the roots of asparagus (Asparagus officinalis L.). Carbohydr. Res., 96, 281-292 (1981).

22) N. Shiomi: Reverse reactions of fructosyl transfer catalysed by asparagus $6^{\mathrm{G}}$-fructosyltransferase. Carbohydr. Res., 106, 166169 (1982)

23) K. Ueno, S. Onodera, A. Kawakami, M. Yoshida and N. Shiomi: Molecular characterization and expression of a cDNA encoding fructan: fructan $6^{\mathrm{G}}$-fructosyltransferase from asparagus (Asparagus officinalis). New Phytol., 165, 813-824 (2005).

24) N. Shiomi, H. Kido and S. Kiriyama: Purification and properties of sucrose: sucrose $1^{\mathrm{F}}-\beta$-D-fructosyltransferase in onion seeds. Phytochemistry, 24, 695-698 (1985).

25) A. Yamamori, S. Onodera, M. Kikuchi and N. Shiomi: Two novel oligosaccharides formed by $1^{\mathrm{F}}$-fructosyltransferase purified from roots of asparagus (Asparagus officinalis L.). Biosci. Biotechnol. Biochem., 66, 1419-1422 (2002).

26) H. Hidaka, M. Hirayama and N. Sumi: A fructo-oligosaccharide-producing enzyme from Aspergillus niger ATCC 20611. Agric. Biol. Chem., 52, 1181-1187 (1988).
27) Y. Kobayashi, S. Onodera, T. Hidano and N. Shiomi: New oligosaccharides synthesized by fructosyltransferase purified from Eurotium repens. in Abstract Book of Annual Meeting of Japan Society of Nutrition and Food Science, AP86, Matsuyama, Ehime (2000).

28) N. Shiomi and S. Onodera: Two oligosaccharides formed by sucrose: sucrose $1-\beta$-D-fructosyltransferase from onion seeds. J. Rakuno Gakuen Univ., 14, 33-41 (1989).

29) T. Omori, K. Ueno, K. Muramatsu, S. Onodera, M. Kikuchi and N. Shiomi: Isolation and functional analysis of gene encoding $\beta$-fructofuranosidase from Bifidobacterium adolescentis G1. in Abstract Book of XXIII International Carbohydrate Symposium, AP192, Whistler, Canada (2006).

30) I. Vijn, A. Van Dijken, N. Sprenger, K. van Dun, P. Weisbeek, A. Wiemken and S. Smeekens: Fructan of the inulin neoseries is synthesized in transgenic chicory plants (Cichorium intybus L.) habouring onion (Allium cepa L.) fructan: fructan $6^{\mathrm{G}}$-fructosyltransferase. Plant J., 11, 387-398 (1997).

31) I. Vijn, A. Van Dijken, M. Lüscher, A. Bos, E. Smeet, P. Weisbeek, A. Wiemken and S. Smeekens: Cloning of sucrose: sucrose 1-fructosyltransferase from onion and synthesis of structurally defined fructan molecules from sucrose. Plant Physiol ., 117, 1507-1513 (1998).

32) B. Henrissat: A classification of glycosyl hydrolases based on amino acid sequence similarities. Biochem. J., 280, 309-316 (1991).

33) V.A. Reddy and F. Maley: Identification of an active-site residue in yeast invertase by affinity labeling and site-directed mutagenesis. J. Biol. Chem., 265, 10817-10820 (1990).

34) A. Reddy and F. Maley: Studies on identifying the catalytic role of Glu-204 in the active site of yeast invertase. J. Biol. Chem., 271, 13953-13958 (1996).

35) T. Ritsema, A. Verhaar, I. Vijn and S. Smeekens: Using natural variation to investigate the function of individual amino acids in the sucrose-binding box of fructan: fructan $6^{\mathrm{G}}$ fructosyltransferase (6G-FFT) in product formation. Plant Mol. Biol ., 58, 597-607 (2005).

36) N. Shiomi, N. Benkeblia, S. Onodera and N. Kawazoe: Fructooligosaccharides changes during maturation in florescences and seeds of onion (Allium cepa L. 'W202'). Can. J. Plant Sci., 86, 269-278 (2006).

37) N. Shiomi, N. Benkeblia, S. Onodera, M. Fujishima and T. Nagamine: Assessment of saccharides and fructooligosaccharides across leaf-bases during bulb development of onion $\mathrm{Al}$ lium cepa L. Acta Agron. Hung., in press (2008).

38) N. Shiomi, N. Benkeblia and S. Onodera: The metabolism of the fructooligosaccharides in onion bulbs: a comprehensive review. J. Appl. Glycosci., 52, 121-127 (2005).

39) N. Benkeblia and N. Shiomi: Postharvest metabolism of carbohydrates in onion and allied crops. in Advances in Postharvest Technologies for Horticultural Crops, N. Benkeblia and N. Shiomi, eds., Research Signpost Publisher, Kerala, pp. 351373 (2006).

40) N. Shiomi, N. Benkeblia, S. Onodera and M. Osaki. Metabolism of fructooligosaccharides in asparagus (Asparagus officinalis L.). in Recent Advances in Fructooligosaccharides Research, N. Shiomi, N. Benkeblia and S. Onodera, eds., Research Signpost Publisher, Kerala, pp. 213-230 (2007).

41) N. Benkeblia, S. Onodera and N. Shiomi: Effect of gamma irradiation and temperature on fructans (fructo-oligosaccharides) of stored onion bulbs Allium cepa L. Food Chem., 87, 377382 (2004).

42) N. Benkeblia, S. Onodera, T. Yoshihira, S. Kosaka and N. Shiomi: Effect of temperature on soluble invertase activity, and glucose, fructose and sucrose status of onion bulbs (Allium cepa) in store. Int. J. Food Sci. Nutr., 55, 325-331 (2004).

43) N. Benkeblia, S. Onodera and N. Shiomi: Variation in 1fructo-exohydrolase (1-FEH) and 1-kestose-hydrolysing (1-KH) activities and fructo-oligosaccharides (FOS) status in onion bulbs. Influence of temperature and storage time. J. Sci. Food Agric., 85, 227-234 (2005).

44) N. Benkeblia, K. Ueno, S. Onodera and N. Shiomi: Variation of fructooligosaccharides and their metabolizing enzymes in onion bulb (Allium cepa L. cv. Tenshin) during long-term stor- 
age. J. Food Sci., 70, S208-S214 (2005).

45) N. Benkeblia, N. Takahashi, K. Ueno, S. Onodera and N. Shiomi: Tetra- and penta- fructooligosaccharide (FOS) isomers assessment in onion bulb tissues: effect of temperature and storage time. Tetrahedron Asymmetry, 16, 33-37 (2005).

46) N. Benkeblia and N. Shiomi: Hydrolysis kinetic parameters of DP 6, 7, 8, and 9-12 fructooligosaccharides (FOS) of onion bulb tissues. Effect of temperature and storage time. J. Agric. Food Chem., 54, 2587-2792 (2006).

47) N. Benkeblia, N. Shiomi and M. Osaki: Kinetics and hydrolysis parameters of total fructooligosaccharides of onion bulbs: effects of temperature regimes and cultivars. J. Food Biochem., 31, 14-27 (2007).

48) N. Shiomi, N. Benkeblia, S. Onodera, T. Omori, N. Takahashi, M. Fjishima, T. Yoshihira and S. Kosaka: Saccharide and fructooligosaccharide contents, and invertase, 1-KHE, 1-SST, 1FFT and 6G-FFT activities in green asparagus spears during storage: effect of temperature and spear portion. J. Appl. Glycosci., 54, 187-194 (2007).

\section{フルクタンと関連糖質およびその合成酵素の 食品生化学的研究}

塩見徳夫 ${ }^{1}$

1 酪農学園大学大学院食品栄養科学専攻 (069-8501 江別市文京台緑町 582)

現在, 天然と化学合成由来のオリゴ糖は 500 種以上を 数え, わが国ではプレバイオティクス効果やミネラル吸 収促進効果等を有する機能性糖質素材として 20 数種が開 発されている.フルクタンの仲間であるフルクトオリゴ 糖もその一種であり, 1-ケストース, ニストースは結晶 品としてAspergillus, Arthrobacter, Aureobasidium, Penicillium, Eurotium, Scopulariopsis などの微生物起源の $\beta$ fructofuranosidase や fructosyltransferase を用いて工業的に 製造されている.このようなフルクトオリゴ糖やフルク タンは植物にも多く存在し, 植物にとって貯蔵炭水化物 として重要な役割を果たしている。ユリ科植物であるア スパラガスやたまねぎにはイヌリン型フルクタンとシュ クロースおよびイヌリン型フルクタンのグルコース分子 の 6 位炭素の水酸基にフルクトースあるいはフルクトー ス鎖が結合したイヌリンネオ型フルクタンが存在してい る。これらの糖の合成経路を精査したところアスパラガ
スではイヌリン型フルクタンはシュクロースから 1-ケス トースを生成する sucrose 1-fructosyltransferase (1-SST) や 1ーケストースからニストースを生成する $1^{\mathrm{F}}$-fructosyltransferase (1-FFT) により合成され，イヌリンネオ型のフ ルクタンはシュクロースおよびイヌリン型フルクタンの グルコース分子の 6 位炭素の水酸基へ選択的にフルク トースを転移する新規 $6{ }^{\mathrm{G}}$-fructosyltransferase (6G-FFT ; 新 規登録, EC2.4.1.243) により，すなわち 3 種の酵素によ り合成されることがわかった。しかし，たまねぎのフル クトオリゴ糖合成は 1-SST と 1-FFT 活性を有する 6G-FFT の 2 種の酵素が関与しており，アスパラガスの場合と異 なっていた。このたまねぎ 6G-FFT と微生物由来 1-SST 類 似酵素のハイブリッドシステムによりシュクロースから イヌリンネオ型オリゴ糖への高効率合成に成功した。イ ヌリンネオ型のフルクタンは, イヌリン型のものと比ベ てビフィズス菌の利用性が高いことから，このネオシ リーズ糖の食品素材としての利用に興味がもたれる。現 在までにこの糖を合成する微生物由来の酵素が見出され ておらず，アスパラガス由来の 6G-FFT の有効利用が期待 される。さらに1-SST, 1-FFT, 6G-FFTのような転移位 置の選択性の高い植物酵素も工業的に利用することがで きれば浸透圧がより低く, 消化管にやさしい新規な構造 を有するフラクトオリゴ糖を効率よく生産できると考え られる。したがって高等植物起源の fructosyltransferase の 大量生産技術を確立するためにアスパラガス，たまねぎ cDNA ライブラリーから 1-SST，1-FFT および6G-FFTを コードする cDNA を単離し，その塩基配列を解析すると ともにメタノール資化性酵母による組み換え酵素の発現 を行い, さらに部位特異性変換による 6G-FFT の機能改変 を試みた。得られた組み換え酵素の性質はアスパラガス 根の精製 1-SST, 1-FFT, 6G-FFTの性質と各々同様で あった。このように植物酵素遺伝子の食品工業への基礎 的利用技術が確立された。一方，アスパラガス，たまね ぎの貯蔵中におけるフルクトオリゴ糖代謝を調査し休眠 打破との関連性も提案した。 